\title{
CORRIGENDUM
}

\section{Impact of genetic abnormalities on survival after allogeneic hematopoietic stem cell transplantation in multiple myeloma}

G Schilling, T Hansen, A Shimoni, T Zabelina, J-A Pérez-Simón, NC Gutierrez, W Bethge, P Liebisch, R Schwerdtfeger, M Bornhäuser, S Otterstetter, EMM Penas, J Dierlamm, F Ayuk, D Atanackovic, U Bacher, C Bokemeyer, A Zander, J San Miguel, A Nagler and N Kröger

Leukemia (2008) 22, 1974; doi:10.1038/leu.2008.254

Correction to: Leukemia (2008) 22, 1250-1255; doi:10.1038/ leu.2008.88

Since the publication of the above article, the authors have identified errors in the names of Dr J-A Pérez-Simón and Dr J San Miguel.
The correct names are shown above.

The authors apologize for any inconvenience caused. 